F. Reprod. Fertil. (1961) 2, 362-368

\title{
SUPPRESSION OF FERTILITY IN RATS BY AN INHIBITOR OF MONOAMINE OXIDASE
}

\author{
W. G. SPECTOR \\ Department of Morbid Anatomy, University College Hospital Medical \\ School, London, W.C.1
}

(Received 10th February 1961)

\begin{abstract}
Summary. An inhibitor of monoamine oxidase of low toxicity and with anti-inflammatory properties ( $\mathrm{N}-[1$ methyl-2 phenoxyethyl] hydrazinium $(1+)$ hydrogen maleate, Compound 1275) was administered to female rats under varying circumstances and found to inhibit fertility. The drug interfered with two reactions necessary for normal fertility: oestrus and implantation of the fertilized ovum. Both these reactions involve vascular changes similar to those that occur in acute inflammation. As a result, it is suggested that the anti-fertility action of the drug is related to its anti-inflammatory properties. Previous results have indicated that the vascular effects of Compound 1275 in inflammation are due to inhibition of the local enzymic inactivation by injury of an adrenaline-like substance. A similar mechanism may explain its antifertility action, although a direct or indirect effect on the endocrine system cannot be excluded.
\end{abstract}

\section{INTRODUCTION}

The fertility of female mammals depends on many different factors, two of these being the development in the uterus of the changes of oestrus and, after fertilization of the ovum, of the phenomena of implantation. Both oestrus and implantation (i.e. the establishment of the fertilized ovum in the uterus) have many features in common with early inflammation (Johnson \& Shelesnyak, 1958; Spector \& Storey, 1958; Shelesnyak, 1959), in particular local dilation of blood vessels and the formation of a protein-rich fluid exudate due to increased vascular permeability to plasma protein, together with emigration of granulocytes. Oestrogenic stimulation undoubtedly plays a large part in the vascular changes seen in both oestrus and nidation.

There are a number of drugs that will cause striking suppression of the vascular events of inflammation, including salicylate, quinine and high doses of anti-histamines. To produce a profound effect over a long period, however, the doses required would be certainly toxic and possibly fatal. On the other hand, the suppression of vascular inflammatory changes by hydrazinium inhibitors of monoamine oxidase described by Spector \& Willoughby $(1960 \mathrm{a}, \mathrm{b})$ was achieved with non-toxic doses. These compounds therefore provided a means of testing the effect of anti-inflammatory drugs on fertility. The substance used in the present investigation was $\mathrm{N}-[1$ methyl-2 phenoxyethyl $]$ 
hydrazinium $(1+)$ hydrogen maleate (Compound 1275). As the initial experiments were commenced, Robson reported on the ability of a monoamine (5-hydroxytryptamine) and of a monoamine oxidase inhibitor (iproniazid) to interrupt pregnancy in mice. These results were subsequently published (Poulson, Botros \& Robson, 1960).

\section{METHODS}

Female albino rats of the Wistar strain weighing between 150 to $200 \mathrm{~g}$ were used. The monoamine oxidase inhibitor $\mathrm{N}-[1$ methyl-2 phenoxyethyl] hydrazinium $(1+)$ hydrogen maleate (Compound 1275; Smith \& Nephew Research Ltd), when injected, was used as a $5 \%$ solution w/v subcutaneously. When given orally, the compound was dissolved in tap water which was then administered ad libitum from standard drinking bottles fixed to the cage.

To examine the cytology of vaginal smears, $0.2 \mathrm{ml}$ of $0.9 \% \mathrm{w} / \mathrm{v}$ sodiumchloride solution (saline solution) was introduced from a Pasteur pipette into the vagina of the unanaesthetized animal. The vagina was gently washed out with this volume of saline solution and the resultant fluid transferred to a clean glass microscope slide. This preparation was then examined fresh under the microscope. Animals whose smears showed epithelial and cornified cells with predominance of the former or epithelial cells alone were considered as possibly able to accept the male in the ensuing 24-hr period and were therefore chosen for mating.

To determine whether mating had taken place, the vaginal washing procedure described above was repeated and the washings examined once more. The presence of spermatozoa was taken to indicate that mating had occurred. The procedure was performed 16 to $24 \mathrm{hr}$ after the addition of the female rats to the cage containing the male animals.

\section{RESULTS}

As an initial experiment, it was decided to cage male and female rats together for a fairly long time and to compare the incidence of pregnancy in control animals with that in rats whose drinking water contained various concentrations of Compound 1275. Female rats were selected without regard to the vaginal smears and given the drugged drinking water for $24 \mathrm{hr}$. They were then caged with male animals (one male for each five or six females) for 9 days during which both male and female rats received drinking water (given ad libitum) containing Compound 1275 at concentrations from 0.1 to $0.5 \mathrm{mg} / \mathrm{ml}$. After 9 days, they reverted to unadulterated drinking water. The volume of fluid drunk was such that each rat received about $25 \mathrm{mg} / \mathrm{kg}$ of the drug in every $24 \mathrm{hr}$. Control male and female rats were treated identically but received tap water without the addition of any drug. All animals receiving Compound 1275 appeared normal during and after the period of administration, showed no weight loss and ate a normal quantity of diet.

It can be seen from Table 1 that, amongst rats receiving the highest dose of Compound 1275, the incidence of pregnancy was zero, compared with $50 \%$ in the control groups. Lower doses of the drug resulted in intermediate effects. 
To determine the reversibility of the effect of Compound 1275 on fertility, twenty-four female rats that had received the drug for 9 days at a level of 0.5 $\mathrm{mg} / \mathrm{ml}$ were mated as above 3 weeks later, on this occasion receiving unadulterated tap water ad libitum. A normal proportion ( $46 \%$ ) of these animals became pregnant and delivered normal litters which survived to healthy adulthood.

TABLE 1

EFFECT OF DIFFERENT DOSES OF COMPOUND 1275 ON THE INGIDENGE OF PREGNANCY IN RATS

\begin{tabular}{c|c|c|c|c}
\hline $\begin{array}{c}\text { Concentration of drug } \\
\text { in drinking water } \\
(\mathrm{mg} / \mathrm{ml})\end{array}$ & $\begin{array}{c}\text { Approximate dose } \\
(\mathrm{mg} / \mathrm{kg} / 24 \mathrm{hr})\end{array}$ & $\begin{array}{c}\text { No. } \\
\text { females }\end{array}$ & $\begin{array}{c}\text { No. } \\
\text { pregnant }\end{array}$ & $\begin{array}{c}\text { Pregnant } \\
(\%)\end{array}$ \\
\hline None & None & 48 & 24 & 50 \\
$0 \cdot 5$ & 25 & 48 & 0 & 0 \\
$0 \cdot 25$ & 12 & 20 & 4 & 20 \\
$0 \cdot 10$ & 5 & 20 & 8 & 40 \\
\hline
\end{tabular}

TABLE 2

GELLULAR CONSTITUENTS OF VAGINAL WASHINGS DURING ADMINISTRATION OF COMPOUND 1275

\begin{tabular}{c|c|c|c|c}
\hline $\begin{array}{c}\text { Days after commencing } \\
\text { dosage with Compound } \\
1275 \text { in drinking water } \\
(0.5 \text { mg/ml })\end{array}$ & $\begin{array}{c}\text { No. rats } \\
\text { with LE } \\
\text { vaginal } \\
\text { smear }\end{array}$ & $\begin{array}{c}\text { No. rats } \\
\text { with EC } \\
\text { vaginal } \\
\text { smear }\end{array}$ & $\begin{array}{c}\text { No. rats } \\
\text { with C } \\
\text { vaginal } \\
\text { smear }\end{array}$ & $\begin{array}{c}\text { No. rats } \\
\text { with E } \\
\text { vaginal } \\
\text { smear }\end{array}$ \\
\hline 1 & 14 & 8 & 1 & 1 \\
2 & 10 & 6 & 0 & 8 \\
3 & 12 & 6 & 0 & 6 \\
4 & 16 & 2 & 0 & 6 \\
5 & 12 & 0 & 2 & 10 \\
7 & 22 & 2 & 0 & 0 \\
8 & 22 & 0 & 2 & 0 \\
9 & 24 & 0 & 0 & 0 \\
10 & 22 & 0 & 2 & 0 \\
11 & 24 & 0 & 0 & 0 \\
12 & 24 & 0 & 0 & 0 \\
\hline
\end{tabular}

Mean weight of animals on Day $1165 \mathrm{~g}$. Mean weight of animals on Day $12175 \mathrm{~g}$.

$$
\begin{gathered}
L E=\text { leucocytes and epithelium } \\
E C=\text { epithelium and cornified cells } \\
C=\text { cornified cells } \\
E=\text { epithelial cells }
\end{gathered}
$$

The results of these initial experiments were encouraging but gave little indication of the mode of action of the compound.

One possible explanation of the anti-fertility effect was the suppression of oestrus. Accordingly, twenty-four female rats were weighed and the cytological picture of the vaginal smear from each animal was recorded daily for several days. Compound $1275(0.5 \mathrm{mg} / \mathrm{ml})$ was then added to the drinking water of these animals for a period of 14 days and the preponderant cells of the vaginal fluid of each rat again recorded daily. At the end of the period of dosage, the rats were weighed once more. The individual animals were identified by marking their coats with 'Furafur' dyes (Imperial Chemical Industries Ltd). 
As can be seen from Table 2, after administration of Compound 1275 for 5 days, vaginal washings usually exhibited a mixture of leucocytes and epithelial cells with preponderance of the former, and rats showing this type of smear invariably failed to accept the male. It can also be seen that in spite of the addition of the drug to their drinking water, the rats did not lose weight during the experiment.

TABLE 3

EFFEGT ON THE INGIDENCE OF PREGNANGY OF ADMINISTERING COMPOUND 1275 TO FEMALE RATS AFTER MATING (VERIFIED BY VAGINAL SMEAR)

\begin{tabular}{c|c|c|c}
\hline $\begin{array}{c}\text { Concentration of Compound } \\
1275 \text { in drinking water }\end{array}$ & $\begin{array}{c}\text { No. female } \\
\text { rats mated }\end{array}$ & No. pregnant & $\begin{array}{c}\text { Pregnant } \\
(\%)\end{array}$ \\
\hline None & 33 & 30 & 91 \\
$0.5 \mathrm{mg} / \mathrm{ml}$ & 33 & 12 & 36.5 \\
\hline
\end{tabular}

It is obvious from the demonstrable ability of Compound 1275 to suppress behavioural oestrus that this action could have played a large part in the suppression of fertility observed in the experiment of which the results are given in Table 1. It is also apparent that the results seen in Table 1 could have been due in part to an effect on the male. To elucidate the role of these actions in the anti-fertility effect and to observe any specific effect of the drug on implantation, a further experiment was devised, the results of which are displayed in Table 3. In this experiment, from a stock of several dozen female rats, animals whose vaginal smears suggested that they might accept the male in the next $24 \mathrm{hr}$ were selected daily and caged overnight with males. As a routine, one female was added to a cage containing two males. The next morning, the females were removed and examined, and those found to have mated (i.e. to show spermatozoa in the vagina) were placed on a regime of drinking water containing Compound $1275(0.5 \mathrm{mg} / \mathrm{ml})$ for 12 days. Control rats mated in this fashion, but given plain tap water, had a pregnancy rate of $90 \%$. The animals treated with Compound 1275 had a pregnancy rate of $36.5 \%$. Thus, although dosage was not commenced until after mating had occurred and the male rats received none of the drug, a considerable reduction in fertility was achieved. This result indicates an effect of Compound 1275 on the early stages of pregnancy, i.e. presumably on implantation, since this process does not commence until 4 or 5 days after mating.

It seemed possible that the results given in Table 3 might be improved if the drug were administered earlier. The experiment was therefore repeated. This time, however, the female rats were injected subcutaneously with a single dose of Compound $1275(50 \mathrm{mg} / \mathrm{kg})$ immediately before their addition to the cage in which the male rats were housed. Moreover, during the overnight mating period both male and female animals received drinking water containing Compound $1275(0.5 \mathrm{mg} / \mathrm{ml})$. The next morning, the female rats were examined as before and those found to have mated were placed on a regime of 
drinking water containing Compound $1275(0.5 \mathrm{mg} / \mathrm{ml})$ for 13 days. The incidence of pregnancy in female rats so treated was $14 \%$, as opposed to $93 \%$ in control rats receiving an injection of sterile saline before mating and plain tap water during and subsequent to caging with male rats (Table 4).

To confirm an action of Compound 1275 on implantation and to exclude an effect on the fertilization and migration of the ovum, a further experiment was performed. The procedure just described, the results of which appear in Table 4, was repeated exactly, but the administration of drinking water containing Compound 1275 was continued only until the 4th day after mating, plain drinking water being given thereafter. It will be recalled that, after mating, 5 days elapse before the fertilized ovum reaches its resting place in the uterus. In this experiment, the pregnancy rate in the mated rats was $95 \%$ (Table 4 ). If dosage was continued for 8 days, an intermediate result was obtained (Table 4).

TABLE 4

EFFECT ON THE INCIDENCE OF PREGNANGY OF COMPOUND 1275 GIVEN BEFORE, DURING AND AFTER MATING (VERIFIED BY VAGINAL SMEAR)

\begin{tabular}{|c|c|c|c|c|c|}
\hline $\begin{array}{l}\text { Injection } \\
\text { before } \\
\text { mating }\end{array}$ & $\begin{array}{l}\text { Concentration of } \\
\text { Compound } 1275 \text { in } \\
\text { drinking water during } \\
\text { and after mating }\end{array}$ & $\begin{array}{l}\text { Duration of } \\
\text { administration } \\
\text { of drug after } \\
\text { mating (days) }\end{array}$ & $\begin{array}{c}\text { No. } \\
\text { females } \\
\text { mated }\end{array}$ & $\underset{\text { pregnant }}{\text { No. }}$ & $\begin{array}{l}\text { Pregnant } \\
(\%)\end{array}$ \\
\hline $\begin{array}{l}\text { Saline solution } \\
\text { Compound } 1275 \\
50 \mathrm{mg} / \mathrm{kg}\end{array}$ & $\begin{array}{c}\text { None } \\
0.5 \mathrm{mg} / \mathrm{ml}\end{array}$ & $1 \overline{3}$ & $\begin{array}{l}28 \\
28\end{array}$ & $\begin{array}{r}26 \\
3\end{array}$ & $\begin{array}{l}93 \\
11\end{array}$ \\
\hline ", " & ", ", & $\begin{array}{l}3 \\
7\end{array}$ & $\begin{array}{l}16 \\
12\end{array}$ & $\begin{array}{r}15 \\
4\end{array}$ & $\begin{array}{l}95 \\
33\end{array}$ \\
\hline
\end{tabular}

Rats receiving Compound 1275 in their drinking water were observed to drink considerably less water than those having plain tap water. Animals being dosed with the drug drank about 15 to $20 \mathrm{ml}$ of water in the $24 \mathrm{hr}$ as opposed to about $40 \mathrm{ml}$ on the part of control animals. To test the effect of reduced water intake on fertility, rats were mated as above, no water being given during the overnight mating period. They were then placed on a regime in which each animal received 15 to $20 \mathrm{ml}$ tap water in $24 \mathrm{hr}$ for a period of 12 days. Normal feeding was maintained. The rats seemed unaffected and of sixteen females mated, fourteen became pregnant, an incidence of $88 \%$.

\section{DISCUSSION}

Results obtained in the laboratories of Messrs Smith \& Nephew Research Ltd showed that twenty-four male and female rats given Compound 1275 by stomach tube $(25 \mathrm{mg} / \mathrm{kg}$ daily for 90 days) gained weight at the same rate as control animals throughout the period of dosage. At the end of the experiment, histological examination revealed no abnormality in any organs, including those of the genital tract. The blood showed normal values for haemoglobin and red cells, with a moderate reduction in the number of circulating lymphocytes and a corresponding increase in granulocytes and monocytes. 
The results of the present investigation interpreted in the light of these chronic toxicity studies indicate a specific effect of Compound 1275 on the fertility of female rats. It appears that this effect possesses two components, suppression of behavioural oestrus, reflected by the cytology of the vaginal smear, and, in rats that have mated, inhibition of implantation of the fertilized ovum. Since the first results of the present investigation were published (Spector, 1960), a similar effect on the oestrous cycle has been reported to follow administration of a less recent and more toxic monoamine oxidase inhibitor, viz. iproniazid (Setnikar, Murmann \& Magistretti, 1960).

Both oestrus and implantation depend upon vascular changes similar to those involved in the acute inflammatory reaction to injury of many types. Previous work (Spector \& Willoughby, $1960 \mathrm{a}, \mathrm{b}$ ) has shown that monoamine oxidase inhibitors cause a striking inhibition of the vascular changes of inflammation, especially increased capillary permeability. An anti-inflammatory effect has also been observed to follow administration of iproniazid (Setnikar, Salvaterra \& Temelcou, 1959). The results obtained by Spector \& Willoughby $(1960 \mathrm{~b})$ indicate that the action of the compound in inflammation is due to inhibition of the enzymic inactivation of an adrenaline-like substance that would otherwise occur at the site of injury. As the result of preservation of the vasoconstrictor amine, it was postulated that local increased capillary permeability was suppressed.

It is clear that a similar mechanism could lead to inhibition of the vascular changes associated with oestrus and implantation. It is also possible, however, that administration of a monoamine oxidase inhibitor such as Compound 1275 might alter the secretory pattern of the endocrine system in a direction unfavourable to fertility. This action could be direct or by way of preservation of an adrenaline-like substance, since released or injected adrenaline leads to stimulation of both anterior pituitary and suprarenal cortex (see Born, 1958).

\section{ACKNOWLEDGEMENTS}

The author's thanks are due to Sir Roy Cameron for his interest and to Messrs Smith \& Nephew Research Ltd for supplying Compound 1275 and for permission to reproduce the results of chronic toxicity tests carried out by them with this substance. The author is indebted also to Miss M. Horn for valuable technical assistance.

\section{REFERENCES}

Born, G. V. R. (1958) Some effects of injury on metabolism. General Pathology, 2nd edn, p. 321. Ed. H. W. Florey. Lloyd-Luke, London.

Johnson, T. H. \& Shelesnyak, M. G. (1958) Histamine-oestrogen progesterone complex associated with the decidual cell reaction and with ovum implantation. $\mathcal{F}$. Endocrin. 17, xxi.

Poulson, E., Botros, M. \& Robson, J. M. (1960) Effect of 5-hydroxytryptamine and iproniazid on pregnancy. Science, 131, 1101.

Setnikar, I., Murmann, W. \& Magistretti, M. J. (1960) Retardation of sexual development in female rats due to iproniazid. Endocrinology, 67, 511.

Setnikar, I., Salvaterra, M. \& Temelgov, O. (1959) Antiphlogistic activity of iproniazid. Brit. $\mathcal{F}$. Pharm. 14, 484. 
Shelesnyax, M. C. (1959) Experimental studies on the role of histamine in implantation of the fertilised ovum. Bull. Soc. belge Gynéc. Obstét. 27, 521.

SpEctor, W. G. (1960) Anti-fertility action of a monoamine oxidase inhibitor. Nature, Lond. 187, 514.

SPECTOR, W. G. \& STOREY, E. (1958) A factor in the oestrogen-treated uterus responsible for leucocyte emigration. F. Path. Bact. 75, 387.

SPEctor, W. G. \& WilloughBy, D. A. (1960a) Suppression of increased capillary permeability injury by monoamine oxidase inhibitors. Nature, Lond. 186, 162.

Spector, W. G. \& Willoughry, D. A. (1960b) The enzymic inactivation of an adrenaline-like substance in inflammation. $\mathcal{F}$. Path. Bact. 80, 271. 